\title{
Producing (im)mobilities in home care for the elderly: the role of home care agencies in Switzerland
}

\author{
By HUEY SHY CHAU*
}

\begin{abstract}
The Free Movement of Persons Agreement has fostered the emergence of a new market for live-in care in Switzerland. Private care agencies recruit women from the European Union (EU) accession states and place them as live-in carers for the elderly in private households. This paper focusses on how these agencies organise these live-in care arrangements. Drawing on concepts of the politics of mobility, I analyse the production of (im)mobilities through the placement and recruitment practices of care agencies and the power relations that underlie live-in care arrangements. The findings show that live-in care is constituted both by mobilities, exemplified by care workers' circular movements and need to be highly mobile, and by care workers' immobilities once they start working in a household. The care workers' mobility is in turn enabled by the agencies' placement practices and by infrastructures specialised in their movements, which serve as moorings.
\end{abstract}

Keywords: home care, mobilities, migrant care worker, intermediaries, Switzerland. 
International Journal of Ageing and Later Life

\section{The Emergence of Home Care Agencies}

"It'd gradually gotten worse. At some point, it was too much for me. So I started to do a bit of research online. I just typed in 'carers from the East' (Pflegerinnen aus dem Osten)," Mr. Schmid explained how he came to use the services of a home care agency. His wife had been diagnosed with Alzheimer's. He had cared for her for five years before he decided to seek help. This situation is not uncommon in Switzerland, where care has always been considered a predominantly private matter (Schilliger 2014; Schwiter et al. 2018). The majority of adults in need of care live in private households and are mainly cared for privately by their partners (EGB 2010). It was not until Mr. Schmid felt that caring for his wife had become too much of a burden that he decided to try a live-in care arrangement with a migrant carer. "This way, my wife could stay at home and I had some freedom," he explained.

Care in the global north is increasingly being delegated to women migrating from poorer to wealthier countries (Raghuram 2016). The rise of migrant domestic workers in Asian and North American countries in the 1990s was mainly attributed to the facilitation of local mothers into labour markets (Constable 1997; Ehrenreich \& Hochschild 2003; Huang $\&$ Yeoh 1996). Since the turn of the century, interest in migrant care work for elderly care seems to have grown. Privately organised live-in care arrangements are increasingly offered as a solution to a care gap in ageing societies. Ever more private households avail care services from a privatised care market. This increasing demand in private home care is also driven by shrinking informal capacities for care in families because of the continuing rise of dual-earning household models, and neoliberal austerity, which have led to shifts from public to private responsibilities for care (Raghuram 2016; Schwiter et al. 2018; Williams 2011).

In Europe, the commercialisation of home care has been accompanied by the emergence of private, for-profit care agencies, who recruit circularly migrating care workers from Eastern European countries and place them in households in the wealthier EU countries (Lutz 2008, 2011; Triandafyllidou \& Marchetti 2013). In Germany and Austria, the surge of live-in care for the elderly was sparked by the introduction of the free movement of workers agreement (AFMP) and the Posted Workers Directive, which allows agencies based in recruitment countries to send workers 
to provide services on a temporary basis (Bachinger 2009; Krawietz 2014; Österle et al. 2013; Rossow \& Leiber 2017). Switzerland does not allow the posting of workers, but it has gradually introduced the AFMP through bilateral agreements with the EU, rather later than EU member countries. The appearance of care agencies and live-in care was first documented in Switzerland in 2009 and mainly in relation to informal arrangements (Schilliger 2009). However, the period since the extension of the AFMP to eight new EU member states in Eastern Europe in 2011 has seen a mushrooming of care agencies officially placing migrant care workers (Schilliger 2014; Truong et al. 2012).

This paper focusses on the role of home care agencies in the commodification of live-in care and sheds light on their recruitment and placement practices. I argue that home care agencies have become important actors in making live-in care accessible in Switzerland and in influencing who performs live-in care and under what conditions. I draw on concepts of the politics of mobility to gauge how migration is enabled and analyse the power relations that underlie live-in care arrangements. Which (im) mobilities are produced through the recruitment and placement practices of home care agencies?

In the following sections, I first provide an overview of the literature on recruiters and brokers in migrant care work. After discussing how the conceptual framework of a politics of mobility enriches my analysis of the organisation of transnational live-in care arrangements, I present the material and methods of this study. The results section explores how care agencies recruit and place carers to private households. In the conclusion, I reflect on the (im)mobilities that constitute live-in care, the underlying power relations and what these mean for future live-in care work.

\section{Migrant Care Work and Agencies}

The delegation of care work to women from poorer countries has gained substantial attention in a growing literature on paid domestic and care work since the late 1990s. The discussions relate to Marxist feminist debates on domestic work and labour reproduction in the 1970s (Kofman \& Raghuram 2015). Much of the literature has focussed on the globally unevenly gendered and exploitative structures of migrant domestic 
International Journal of Ageing and Later Life

work, most prominently captured by the concept of global care chains (Ehrenreich \& Hochschild 2003; Hochschild 2000; Parrenas 2000; Yeates 2004, 2012). The global flow of care has been further conceptualised as the care diamond (Raghuram 2012; Razavi 2007) and most recently as care circulation (Baldassar \& Merla 2014). The care diamond recognises that the provision of care involves multiple institutions, and care circulation observes that care does not only flow in one direction but is multisited and occurs through asymmetrical reciprocal exchange within transnational families. The literature on global care chains and care circulation includes important insights into the gendered and unequal distribution of care, migration patterns, transnational working and living conditions, and processes within transnational families. Less is known about how migration for live-in care is in fact enabled. This knowledge gap has been referred to as the "black box of migration" (Lindquist, Xiang \& Yeoh 2012). Notably, the role of labour migration brokers has not been sufficiently examined.

While many studies have mentioned the role of agencies as a subtopic, relatively few have taken them as a main unit of analysis in migrant care work. Some scholars have focussed on the role of agencies in enabling employers to find carers and examined how agencies gain access to care workers. In a study in Los Angeles, Hondagneu-Sotelo showed that the agencies depict themselves as indispensable matchmakers to employers, who seek "idiosyncratic traits, such as personal compatibility" (Hondagneu-Sotelo 1997: 5). Focussing on a subsystem of local recruiters and informal intermediaries in Indonesia, Lindquist $(2010,2012)$ showed that agencies can play a key role in creating trust between would-be migrants and employers. Other studies stress the important role agencies play in facilitating complicated bureaucratic procedures to enable migration and in elevating standards for migrants (Goh et al. 2017; Kern \& Müller-Böker 2015). In Europe, scholars have noted that care agencies often work with recruitment agencies in the recruitment countries to access care workers (Bachinger 2009; Krawietz 2014; Rossow \& Leiber 2017). Another strategy is to encourage informal networks of carers to recommend other care workers to the agency (Schilliger 2014). Elrick and Lewandowska (2008) showed that many agents in Poland were deeply embedded in migrant networks; these authors argue that they play a significant role in continuing migration flows. 
Another strand of literature focusses on the production of stereotypes based on gender, nationalities, and other markers of identification fostered by employers and agencies. The stereotypes have been discussed as ethnicisation (Abrantes 2014; Bachinger 2009; Krawietz 2014; Schwiter et al. 2014) and racialisation (Bakan \& Stasiulis 1995; Guevarra 2010; Hondagneu-Sotelo 2000; Liang 2011). Moreover, studies have shown that recruiters actively create divisions and hierarchies between workers. Hondagneu-Sotelo (2000) demonstrates that women from Englishspeaking countries are placed in the United States as nannies, whereas women from Latin American countries are matched to households for domestic work. Similarly, Loveband (2004: 336) shows that Taiwanese agencies distinguish between domestic workers from Indonesia and the Philippines in ways that lead to Indonesian women often "doing the dirtier and more demanding jobs." Hence, the way that brokers promote essentialist stereotypes channels workers into specific sectors of the labour force.

The traits that agencies seek and promote in-care workers vary according to context. In their study on Sri Lankan domestic workers in the Middle East, Eelens and Speckmann (1990) observe that agents preferred to recruit women from rural places, as they are deemed to be more accustomed to hard work. Focussing on migrant carers in Taiwan, Liang (2011) finds that agencies look for naïve, childlike, innocent characteristics in applicants, who can be transformed into submissive and obedient workers by training centres. In Europe, scholars have found a very different idealised picture of live-in migrant care workers. Recruitment agencies portray care workers as devoted, family-oriented, mature women from Eastern European countries with traditional values and the skills to adapt to their places of work (Bachinger 2009; Krawietz 2014; Schilliger 2014).

In sum, studies have shed light on the subjectification of care workers, the creation of local and global divisions between workers, and the role of agencies as gatekeepers into labour markets. Much of this research, however, presumes the existence of such labour markets and emphasises the power of agencies as gatekeepers. Relatively little is known about how home care agencies organise transnational care arrangements at a mundane level. Moreover, little is known about the role of home care agencies 
International Journal of Ageing and Later Life

as key drivers in the commodification of care from informal live-in care arrangements to the establishment of a formal market. This paper relates to these discussions by focussing on the practices, discourses, and infrastructures that actually enable movement in live-in care.

\section{The Politics of Mobility}

To analyse the organisation of live-in care arrangements, I draw on conceptual debates known as the "new mobilities paradigm" (Cresswell 2006; Sheller \& Urry 2006; Urry 2007). The "mobility turn" arose in response to sedentarist theories in the social sciences; these theories consider a sedentary form of life tied to bounded places to be the norm (Sheller \& Urry 2006). Instead of understanding stability and bounded places as basic units in social research, mobilities scholars focus on the movement of people and things. Hence, the mobility turn marks a shift within the social sciences from a "metaphysics of fixity to a metaphysics of flow" (Cresswell 2006: 25). However, unlike debates focussing on deterritorialisation processes, which celebrate mobility and liquidity in a global world and so tend to neglect the importance of space and place in social sciences, the new paradigm does not abandon the notion of fixity altogether (Sheller \& Urry 2006). Instead, fixity and movement form a dialectic relationship that underpins social life. Mobilities are enabled and supported by immobilities, or what Urry (2003) calls "moorings." Correspondingly, mobilities scholars often examine mobilities and movement in relation to notions of fixity, immobility, and moorings; they pay attention both to social and spatial relations and to infrastructures of mobilities, and hence foreground the fact that movement is never without context.

Recently, scholars have also called attention to the "larger apparatus of power in which (these) relations of mobility are situated and governed" (Sheller 2016: 17) and outlined approaches to a politics of mobility (Adey 2006; Cresswell 2010). In politics, Cresswell (2010: 21) includes the "social relations that involve the production and distribution of power." Accordingly, a politics of mobility addresses the question of how mobilities are produced as well as how they create social relations. He sees mobility as a "resource that is differentially accessed" and distributed, and he proposes thinking about who moves to where and how mobility 
is presented and embodied (Cresswell 2010: 21). Moreover, he considers six aspects of movement: why, how fast, in what rhythm, what route, how does it feel, and when and how does it stop (Cresswell 2010).

The focus on mobilities in care work has increasingly gained attention, as the number of studies in home care, some more loosely related to the new mobilities paradigm, shows (Baldassar \& Merla 2014; Cuban 2013; Cuban \& Fowler 2012; Huang et al. 2012; Schwiter et al. 2014). The questions of power relations and mobility, however, are nothing new; they have a long tradition in feminist political economy approaches to social reproduction and in feminist geographers' research into gender and work long before the mobility turn (Cox 2006; Hanson \& Pratt 1995; Mahler \& Pessar 2001; Massey 1993). Scholars have recently called for a framework that more explicitly unites the mobilities concept with research on movement between places in relation to gender, work and power relations (Cresswell et al. 2016; Dorow \& Mandizadza 2018; Dorow, Roseman \& Cresswell 2017; Roseman et al. 2015). Termed employment-related geographical mobility, this concept calls for "looking at the way in which forms of mobility are either enabled by, or impeded by, other forms of (im) mobility" across different scales and for understanding the connections between them (Cresswell et al. 2016: 1792).

Using the new mobilities paradigm, this paper enquires into the (im) mobilities that constitute live-in care for the elderly. I focus on the role of care agencies in the production of (im)mobilities through their recruitment and placement practices. I consider who are selected as carers, in what rhythm they travel back and forth between their homes and places of work, what routes and forms of transport they take, how fast they are employed and their different starting points. I use these insights to shed light on the politics of mobility in the organisation of live-in care arrangements.

\section{Data and Methods}

The research presented here was conducted in line with ethical guidelines in qualitative and feminist research ethics (Denzin \& Lincoln 2011; Hesse-Biber 2012). The empirical material is based on in-depth interviews with 20 representatives of 13 care agencies in Switzerland, Hungary, and 
International Journal of Ageing and Later Life

Slovakia and with 13 carers from Poland, Hungary, and Slovakia between 2013 and 2016. The sample includes a wide range of agencies, from one-person businesses with around 10 care recipients to well-developed agencies with more than 100 care recipients. The sample also covers a range of price segments from $2000 \mathrm{CHF}$ (ca. 1620 Euros) ${ }^{1}$ per month up to more than 12,000 CHF (ca. 9720 Euros) per month. I also conducted interviews with a care recipient, a trade unionist, and a representative of the State Secretariat for Economic Affairs to gain information on the legal context and development of placement practices. My material consists of recorded and transcribed interview data, informal conversations, field notes, and documents related to the marketing and working conditions of live-in care work ${ }^{2}$. The interviews were conducted in German (21), Hungarian (9), and Slovakian (6). The non-German interviews were translated into English by field collaborators. Of the 36 interviews, 20 were fully transcribed verbatim, and seven were partially transcribed. I use fictive names for all interviewees, and I anonymised them so that links cannot be traced between them and specific business practices.

I used grounded theory methods according to Charmaz (2014) to analyse the material. Drawing on Strauss and Corbin (1990), Charmaz proposes two main coding phases, initial and focussed coding, before writing up the results. Initial coding moves quickly through a large amount of data from selected interviews and stays close to the data. In contrast, the purpose of focussed coding is to first establish analytic directions by grouping codes into categories, which are then applied to the rest of the material (Charmaz 2014). Accordingly, I applied initial coding to full transcripts of eight interviews with care agencies, a group conversation with

${ }^{1}$ CHF was equivalent to around 0.81 EUR in May 2014. Exchange rates of 15th May 2014 calculated according to the online currency converter XE ('XE Currency Converter' 2017).

2 During fieldwork, I visited a care agency in Slovakia, travelled by car with a care agent and care workers from Slovakia to Switzerland, and accompanied carers when they arrived at the households to start their employments. I visited an agency and a group of care workers in their home village in Hungary. I visited another carer at her place of work in Switzerland and in her home village in Hungary; there, she took me to a café where a group of nine care workers met for coffee and discussed the organisation of live-in care work. I also intermittently visited the group Respekt, a group of care workers that advocates for improved working conditions in live-in care. While out in the field, I took notes of my observations and wrote down aspects I had learnt in these situations. 
carers in Hungary, and three interviews with carers using the MaxQda analysis program. Subsequently, I grouped the codes into categories and used these to sift through the rest of the material. While doing so, I added new codes to categories, and renamed and merged codes into subcategories. The subchapters in this paper correspond to key categories relevant to the recruitment and placement of care workers. I kept the coding process in two separate projects: one with care agencies and one with carers. The material in this paper is partially linked by ideas on mobile ethnography (Büscher \& Urry 2009; Faist 2012). The concept addresses the spatial movement of people through direct observation of associated social practices. Although it had not been my initial intention, my material turned out to provide a fruitful insight into practices that result in mobility and immobility in live-in care work. For this paper, I chose particular moments and quotations that I consider relevant for the reader to understand how live-in care work is organised.

\section{Mobilities that constitute live-in care arrangements}

\section{Live-in Care as All-Inclusive Deals and Win-Win Situations}

Many agencies offer package deals for differing levels of care dependency. Designed as all-inclusive offers, the packages include matching with carers, the organisation of their arrival and departure, administration such as wage accounting, registration with social insurance offices, taxes and applications for residence permits. Once care agents have identified possible carers for a household, they often forward a selection to the care recipients and their family members. Moreover, care agencies offer to replace carers in case the relationship between the elderly care recipients and live-in carers do not develop as expected. What is also remarkable is how fast a care arrangement can be organised: "Uncomplicated and fast," one of the care agencies advertises, "it takes a maximum of 60 minutes' effort. You can welcome a carer at your door after 6-10 days."

With the development of a broad landscape of agencies offering all-inclusive home care deals, and with costs starting as low as CHF 1600 (ca. 1300 EUR), it has become much easier for the elderly and their families to access live-in care. Not only is it possible to gather information and compare offers on agencies' websites but also to book their services online. 
International Journal of Ageing and Later Life

In this sense, home care agencies are a crucial entry point for the elderly and their family members to a live-in care arrangement. For example, Mr. Schmid would not have hired a live-in carer on his own: "I'd never do that. Firstly, because of the permits. (...) Then there's social insurance, old age insurance, unemployment insurance, then the benefit plan. This is all really complicated." For him, the fact that he was not responsible for organisational work was decisive.

Some of the care agencies, especially those in the low-cost segment, market their offers as a win-win solution:

\footnotetext{
For many Swiss it is not possible because of financial reasons to afford 24-hour care from local service providers. (...) The carers (...) are in a similarly difficult situation. The care employment offers them the possibility to work in the profession they were trained in and earn a much higher salary than in their home country. Hence, after their stay in Switzerland - where they can get to know a new culture besides the work and improve language skills - they go home with a good financial situation. Therefore, both parties benefit. (Website of a care agency, 2015. Translated from German by author.)
}

This is not surprising, as this marketing strategy aligns with the win-win logic of circular migration policies (Castles 2006; Wickramasekara 2011). Therefore, the fact that care workers have to travel far is concealed in all-inclusive packages, and carers' movements and mobility are represented as part of a win-win situation.

\section{Travelling Back and Forth and Repeated Short-Term Assignments}

The agencies organise various forms of working arrangement, sometimes according to the care-recipients' preferences. Some arrangements consist of two carers who rotate every few weeks in the same household and who go back and forth between Switzerland and their home country. For instance, one of the larger agencies in the high-price segment employs carers for two weeks without a free day and rotates them every two weeks. Other agencies' main operating model replaces a carer in a household after three months or less, so that an elderly person is cared for by at least four different carers during a year. The reason for this is connected to migration regulations. Within the AFMP act, EU nationals working less than three months in Switzerland only have to register their stay online. Workers staying longer have to apply for a residence permit and pay health insurance. 
With the model of constant placements of new care workers, agencies can offer live-in care for lower costs. Other agencies organise a mix between regular rotation and short-term placements. For example, the agency that Mr. Schmid had engaged typically organises repeated two-month assignments with the same carer and one-month reliefs in between, with the person on relief changing every time. For care workers who are frequently placed into new households, this can be tiring. Having to get acquainted with "a new environment, a new situation, a new disease, a new person every time is very exhausting," as Marina, a live-in carer from Hungary, stressed. All of these work arrangements are legally permitted, as long as the agencies are based in Switzerland. However, the sample also includes two agencies that were based in Slovakia and Hungary; these illegally employed the model of constant placement of new care workers, sometimes without registering the care workers with the local authorities.

The agencies organise both the match with a household and the care workers' trips from door to door. Some require carers to travel with them, while others let them travel on their own if they cover additional costs themselves. In my sample, only one of the agencies in the upper price segment had organised the care workers' trips by booking flights. All the others collaborated with transport businesses in the recruitment countries. The use of private transport businesses can facilitate the organisation of the journey as well as the journey itself. It can even be less expensive than public transport. However, the bus journeys are often long and tiring and, depending on the agency and transport business, more or less uncomfortable. The care workers I met in the café in Hungary were very aware of the advantages and disadvantages of traveling with an agency. "It is a great help for those who use the service of an agency. But this help has its costs. You are very constrained," one of them explained. If care workers have to travel with an agency, they may incur inconveniences such as longer traveling times, reduced comfort and restricted luggage space. "And they go around the towns. They stop in between. They don't go a direct way," another care worker says in the group conversation. "Imagine, they picked me up at 4 p.m. (...) [and then in the] morning at 4 a.m. I arrived. They took me all over [the place]," she recalled her experience.

If care workers have to cover the costs themselves, it can play a role in their choice of transport. "Some families pay for the travel, some don't, 
International Journal of Ageing and Later Life

so in this case, you would just look for the cheapest option," one of the care workers explained. Kata, a care worker from Hungary, takes an 11-hour bus ride to reach her place of work. In contrast, Anna, also a care worker from Hungary, takes a flight from Budapest to Zurich. Anna is paid a daily rate of CHF 120 (ca. EUR 97) salary and an additional CHF 600 (ca. EUR 486) per month that her employer agreed to contribute for travel costs, so she is willing to spend higher costs for more comfortable transport than Kata, whose salary is much lower at 50 Euros per day. Therefore, care workers may experience very different journeys in terms of duration, costs and comfort, depending on their financial means and agencies' travel organisation. The more care recipients are ready to pay for transport, the more comfortably they can travel without having to pay extra out of their own pockets.

\section{Building Pools of Care Workers}

Live-in care services are characterised by the interchangeability of care workers, who can be placed relatively fast. This disposability and flexibility constitute an integral part of care agencies' business model, so how do they achieve this? Many of the agencies interviewed build pools of care workers. What is striking is the size of some of the pools, especially in relation to the numbers of care recipients. For example, Daniel's placement agency had built a pool of around 500-600 potential care workers. However, only 110-120 were placed for 100 care recipients at any time. He explained:

(...) you have to have a large pool to be able to react to all demands. And then, as I said, not every customer is the same, I don't want to standardise anyone, so we need as many different carers as possible that can be matched to the individual clients.

His agency was able to organise a care arrangement as fast as within 72 hours. "Flexibility is at the heart of this business," he states, "without flexibility, the business model does not work." Hence, Daniel legitimises the need for the large pool of carers by prioritising the need to satisfy demand.

Employment agency owner Pascal had built a pool of 32 care workers. He had placed carers with five care recipients. Although care workers can only work up to three months per year with him, he does not consider 
how they are able to reconcile such placements with their jobs and activities at home to secure another income than working with his agency:

I have a lot now who don't work with me, who work in Germany. I don't care who they work with there. But I don't want, if I call, and I need them, that they say they are in Germany. Then I say, you have to decide now where you want to work, with me or in Germany.

Hence, Pascal delegates the responsibility for organising a stable income to the individual care workers. Another agency had built a pool of 150 care workers. The agency's recruiter, Andrea, explained that often it was not up to her to decide when a placement began, as many of their clients would be released from hospital and need 24-hour care at home right away:

So we always say, the more flexible you are, the better for you. If they tell me that they're only able to start next week, but in the meantime a placement comes up, then it's too bad for them. Then we ask the next person. If they tell me they're sitting on suitcases that are already packed, able to take a plane the next morning, then it's better for them.

Similarly to Pascal, Andrea makes clear that being flexible would be in the carers' own interest if they want to increase their chances of a placement. Consequently, the agencies create conditions in which carers have to be mobile and flexible in order to be employed.

\section{Subjectivising Care Workers as Mature, Warm-Hearted, Highly Motivated Women from Eastern Germany and Eastern Europe}

Recruitment involves three key points that are relevant in understanding the (im)mobilities required for live-in care arrangements. The first point concerns where carers are recruited and the ascription of "warm-hearted" characteristics to these places. Live-in care arrangements are clearly not meant for local carers, as care agent Livio puts it:

Imagine, a woman comes here as a live-in carer, starts to save money, and starts to pay rent for her own apartment. And then her boyfriend joins her (...), they live together. Maybe they have a couple of kids. Now, (...) is this woman supposed to sleep and live in the care recipient's house? Forget it! (...) This model is not suitable for [permanent] residents [in Switzerland].

Hence, live-in care work is supposedly irreconcilable with having one's own family in spatial proximity. The care workers are not supposed to 
International Journal of Ageing and Later Life

centre their lives in Switzerland, but in what is conceived as "their own home" in the recruitment countries. Correspondingly, the salary that live-in carers receive is usually not sufficient to live in Switzerland. As a consequence, and because live-in carers usually have to be on call around the clock, they lack the chance to build social relations outside the care arrangement (Chau et al. 2018). Live-in carers are effectively immobilised in the households by the specific characteristics of 24-hour care work.

In order to legitimise the recruitment of non-local carers, some of the agents expressed essentialist claims about the traits of carers from specific places (Pelzelmayer 2016). Care agent Pascal, who only recruits from Hungary, claims that "people from the eastern countries have a different moral concept than we do. (...) The Hungarians, they're the closest to us as far as ethics and values are concerned." Dominik, another care agent, legitimises the recruitment more generally from Eastern European countries by comparing it with the recruitment of another agency, the only one in the sample that recruits from eastern Germany and not from the EU-8 countries: "For us Swiss people, High German is a little bit arrogant. And the Germans are a little bit more quick-tempered, faster, and arrogant. They are not as warm-hearted (herzlich) as people in the Slavic parts of Eastern Europe." Therefore, Dominik ascribes a supposedly warm-hearted character to people from places in Eastern Europe, to the extent that he would not recruit carers from other countries. These recruitment practices lead to uneven access to live-in care work. By actively associating people from Eastern Europe with a character that is warm-hearted and has a better work ethic towards the elderly than carers from Switzerland or other places, they reproduce an otherness that marks care workers from Eastern Europe as supposedly more suitable for elderly care.

The second key point is related to the care agents' construction of carers as selfless people with a heart for the elderly. Many of the agents interviewed tend to prioritise a particular attitude over relevant skills or experience in the health sector. "Anybody can do it. No qualifications are needed. It's just housework," said care agent Pascal. However, he emphasised the importance of the applicants' motivations to selection: "If someone asks from the start how much can I earn, how much free time do I have, then I say, well, okay, I won't call you anymore." Care agent Daniel stressed "warm-heartedness (Herzlichkeit) and the will to help someone" 
as important criteria. He argued that lateral entrants were sometimes even more suited for live-in care than professional care workers. Another agency even recruits retirees as care workers. When I asked Andrea about selection criteria, she answered:

The helper syndrome, the heart in the right place. That is essential. (...) If one's willing to work but maybe not trained professionally, that doesn't automatically mean rejection. Because it's empathy that one must have, willingness and kindness (...). Why does she want to do this work? Is it about money? Or, are they retirees who really want to be active and help?

The quotations imply that professional health care skills and experience are secondary to the motivation of potential carers and that the motivation should not derive from financial interest in a job but rather from some kind of inner urge to help the elderly. The binary classification of applicants into whether they were motivated "to help" or primarily interested in money exacerbates the underlying problems of care work as undervalued employment, which ultimately benefit employers and care agencies (McDowell 2009). The definition of care work as not requiring professional skills can be understood as a legitimisation of the low salaries; according to Akalin (2015: 72), it "is an intervention on the part of the employers pursued precisely to increase yields from their workers in every sense." Moreover, the image of a warm-hearted, kind, and selfless person seems to envisage the carers as a family member rather than an employee. In this context, Schilliger (2014) has noted that the portrayal of carers as family members serves to legitimise the blurring of boundaries between working and free time and to justify longer working hours.

A third key finding concerns the role of the recruiters in understanding care work as a gendered activity. Their recruitment practices can be located within existing conceptions of gender norms. According to Bock and Duden (1976), domestic work was transformed into a "labour of love" and constructed as the natural domain of women in the capitalist development of industrial societies. The delegation of care work to another woman is hence accepted to a large extent, because it stays in the logic of "doing gender" (Lutz 2005). Correspondingly, many recruiters explain that care recipients and their family members would prefer women as carers. Yvonne, managing director of an agency, states: "Most elderly women won't accept a man. That's generally a problem in health care." 
International Journal of Ageing and Later Life

Why women are considered more suitable for live-in care, however, was only vaguely answered. Care agent Dominik for example, said: "[they are] just more warm-hearted (herzlicher), the mother instinct, I don't know what kind of thinking, I mean, if you look at old age homes, there too it's women carers. That's why."

What is striking is that many care agents prefer to recruit women of a certain age. Krawietz (2014) finds in her study on the transnational organisation of live-in care in Germany that higher age is portrayed as a competence that would specifically qualify for live-in care work. "Most of our women are between 45 and 60. We don't have women under 30. Well, we had bad experiences with some. And if they've got young kids, then they're also less worth thinking about," said Dominik. Apart from the consideration that "they're not separated from their children for a long time," another reason for employers to avoid women with children is that care workers are entitled to family allowances, which employers have to pay. This would make live-in care more expensive. Moreover, some of the care agents implied that older women prefer to lead a quiet life at home, while young women would want to go out and have a social life. I was also told that older women usually have a family back home and so would not attempt to settle permanently in Switzerland. Care agent Livio even used age to justify difficult working conditions, implying that older women would supposedly be able to better handle rough working conditions because of their life experience: “Don't imagine they're young girls. (...)These are mature 50-year-old women, they've raised children, maybe gone through a second divorce in Poland (...) They come from very tough private circumstances." In this sense, care agencies reproduce the discourse of care work as a gendered domain by predominantly selecting women, and in our case, women of a certain age. Thus, women with young children and men are "structured out of mobile reproductive work" (Dorow \& Mandizadza 2018: 8).

To conclude, recruiters select care workers by gender, recruitment locations, age, family situations and more elusive criteria such as the motivation and mentality of applicants. These recruitment practices characterise live-in carers in Switzerland as older, warm-hearted, highly motivated women from eastern Germany and Eastern Europe. By engaging in spatially selective recruitment of workers from Eastern Europe, and by linking the places to specific traits supposedly required for care work, 
care agencies contribute to the creation of stereotypes and discriminate against would-be care workers from other places. Consequently, their recruitment practices actively contribute to the construction of a gendered migration channel from Eastern European countries to the Swiss live-in care labour market.

Despite a coherent portrayal of who is deemed adequate to perform live-in care work, the results show that there is no clearly defined job profile for live-in carers. Instead, the key criteria in the selection of carers depend on the business models and marketing strategies of the various care agencies. Within the same labour market, the agency that Andrea works for only recruits from eastern Germany, underlining the importance of language skills, while Dominik only recruits from Slovakia and Poland because of the supposedly "warm-hearted character" of a care worker from these places and Pascal only recruits from Hungary because of the supposedly similar work ethics of Hungarian carers and Swiss carers. Another differentiation in recruitment can be observed in relation to the experience of the agents in the health care sector. Care agents who stress that anybody is able to do care work such as Pascal and Dominik, neither of whom have experience in the health care sector, seem to look for "not too dominant" and "devoted" carers. In contrast, care agents that have strong backgrounds in care work emphasise that care work is demanding and hard work and requires carers to have strong communication skills and the ability to stand up for themselves. Thus, the weightings of selection criteria do not follow a uniform logic across the care agencies, and selection mirrors divergent conceptions of what qualifications a care worker should have.

\section{Differential Mobilities of Care Workers}

How fast would-be care workers find themselves on their way to a placement in Switzerland depends not only on the recruitment practices but also on the backgrounds that constitute live-in carers' starting points and their own perception of whether they are ready for the job. Sara, a care worker from Slovakia, had only applied around 10 days prior to her first placement. She had lived in Switzerland before. After graduating in psychology in Slovakia, she had trained as a care assistant in Switzerland, where she learnt German. She had been temporarily unemployed when 
International Journal of Ageing and Later Life

she came across a job post on Facebook. "I called and she [the recruiter] said, send your CV and we'll see. Everything went very fast. Within two days she called me to say, yes, so we have a man, he needs help. (...) And so I said, yes okay, I'll try this," Sara recalled. She was surprised that she got the job so fast. Ilona's case, a care worker from Hungary, is entirely different. Having worked at the post office in the village since she was 18 years old, she had been toying with the idea of going abroad as a carer for a long time. "The children have grown up, see, and you'd like to fly off a bit and you'd like to do something else" she said. In order to prepare for her first placement, she started to attend German classes in the village, which was organised by the agency that recruited her. While many of the care workers who registered with the agency later than Ilona had already gone to placements, Ilona had not by the time we spoke. Why are some care workers readier than others to venture into live-in care work?

By comparing her own background with other care workers, Ilona was very much aware that the women in her region leave from highly diverse starting positions. Her situation presented four salient aspects. Firstly, she felt that her German skills were not as good as other care workers yet. Her cousin, for example, already knew German. Thus, "her language knowledge was very suitable," when the agency first came to their village, she explained. Moreover, Ilona mentioned a woman that had only recently joined the agency but had long-term experience as a care worker in private placements. That woman had been commuting between her assignments in Germany and in Switzerland for years. In contrast, Ilona did not have any experience in live-in care work. Secondly, Ilona's plan to work abroad was not only to seek adventure; she also took financial issues into account. However, she was not in immediate financial distress, as she had been employed in a stable job for many years. In contrast to her cousin, who in Ilona's words was "more forced into it financially," she was not dependent on working as a live-in carer to secure her income but considered it as an option to improve her financial situation. Thirdly, it seems to be easier for those who have fewer ties and, in her words, "constraints here at home," such as family. "She [the cousin] doesn't have a husband, she's single. And she can arrange to go next to her job [in Hungary]," Ilona explained. In contrast, Ilona has three children and a husband from whom she did not want to be away when the children were younger. Now that her two older sons were attending university, her idea to work as 
live-in carer became more feasible. The only downside Ilona saw in live-in care work was that the agency only enables care workers to work three one-month assignments per year, leaving the care workers without any income for the rest of the year. This was not compatible with her job at the post office, and she would have to resign from her job. Therefore, fourthly, going on a home care placement is decided by whether would-be care workers are able to reconcile placements abroad with their own activities and jobs at home as well as by the length and stability of the care work arrangement itself. The decision to go on placement can thus be seen to depend on these four aspects: language skills and care work experience, financial situations, family situations and compatibility of placements with employment situations at home.

The four aspects form a useful basis for a comparison with Sara's starting point. Sara had a degree in psychology, was trained as a care assistant and spoke fluent Swiss and German when she applied for her job as a live-in carer. The placement was temporary, for just two months. Consequently, Sara, who was not married, did not have children and was unemployed at the time, felt able to more or less spontaneously venture on her first placement. Hence, Sara has higher capacities than Ilona for mobility and for venturing into live-in care. In comparison to her cousin and to Sara, Ilona's financial stability, employment in the village and ties to her family can be understood as immobilities that compromise her capacities for mobility. This shows that care workers may experience difficulty in reconciling live-in care work with their own activities and jobs at home. This is especially so when working with agencies that place care workers in short assignments and do not guarantee a stable income. Hence, the working arrangements that care agencies offer play a role in care workers' access to live-in care work, as does whether agents take the stability of care workers' incomes into consideration.

\section{Conclusion}

Home care agencies offering all-inclusive home care play a key role in shaping live-in care by managing the spatial and temporal aspects of care workers' geographical mobility: that is, the (im)mobilities required to enable a live-in care arrangement. As I have shown, care agencies produce a particular system of mobilities, and this shapes live-in care 
International Journal of Ageing and Later Life

migration as a form of movement characterised by repeated short-term and "just-in-time" assignments and frequent changes of households. The care agencies require a relatively high capacity for mobility from the care workers: they should be able to start a job at short notice and travel back and forth between their own homes and their workplaces. The greater the capacity for mobility that prospective care workers possess, such as being able to leave at short notice and not having to take care of small children at home, the more access to live-in care work they have and the more likely they are to be recruited and placed in a household. Hence, caring for care recipients in their own homes is only made feasible by care workers' readiness to be mobile. Moreover, care agencies offer all-inclusive home care packages with salaries that, while affordable to care recipients and their families, are not enough for care workers to live in Switzerland. This produces a degree of isolation for the carers at their workplaces; in other words, it immobilises them in the households.

I also showed that care workers' comfort in their journeys depends not only on their own financial means and access to various transport services but also on whether care recipients are willing to cover their travel costs and on care agents' organisation of journeys. What becomes apparent is the asymmetry in the triangular relationship between care recipients, care agencies and care workers. The main people making decisions in the matching process are usually the care agents and the care recipients. The care workers have relatively little control in comparison; after being selected, they are usually only left with the choice whether to accept or decline whatever employment is offered to them. In cases where carers are asked to begin a placement as fast as possible, those that are flexible enough to accept the conditions and start work the next day have an advantage over those who need time to organise their journey. Care agents try to increase a flexible disposition by creating pools of workers. Speed matters in the matching process. The higher the readiness of care workers, the faster they can be placed, the more care recipients and care agents benefit. Hence, those that are more flexible can actively weaken the opportunities of care workers that are less flexible. As shown above, the latter are usually those with families at home in need of care. Consequently, it is not just other care workers that can be affected by this requirement for readiness but also the families of the carers themselves, who have to support this flexibility and organise their everyday 
lives accordingly. Practices such as online video chatting to maintain relationships with family, the sharing of experiences through Facebook groups and even the provision of food to the left-behind elderly in the carers' home villages are important moorings for care workers' capacity for mobility.

In sum, live-in care arrangements are constituted by a set of (im)mobilities embodied by care workers' capacities for mobility, their repeated movements between their homes and places of work, and their isolation once they have started work in private households. The mobility of care recipients' family members, or "freedom" in Mr. Schmid's words, is anchored in care workers' readiness to be mobile and in their immobility once they arrive at the households. However, care workers' immobility in a household should not be seen as an absolute mooring but as a relative immobility. It is fluid in the sense that care workers do not stay in a household forever. On the contrary, they leave the household after a period of between two weeks or three months, and they move back and forth between Swiss households and their own homes in the recruitment countries. The carers' geographical mobility is in turn enabled by the care agencies' placement practices and growing infrastructures specialised in their movements, such as transport businesses, which serve as moorings.

This specific form of movement for live-in care work is not a coincidence, but the result of an interplay between the profit-maximising business practices of agencies and migration and labour regulations. The practices that enable live-in care arrangements through migrant workers are linked to societal negotiations of how to understand new family relations and responsibilities in care work. Care agencies contribute to the production of an unequal division of care labour in the transnational context. However, the development of private for-profit live-in care agencies has not gone unnoticed. On the contrary, it has moved to the forefront of mass media and public discussions. Trade unions, migrant worker organisations, departments of equalities in various cities and politicians have approached this development as an opportunity to negotiate carers' working conditions (Chau et al. 2018; Schilliger 2015).

Live-in care of the elderly by women migrant care workers in Switzerland is based on two main inequalities: an unequal distribution of care work between men and women and unequal working and living 
International Journal of Ageing and Later Life

conditions between migrant workers and locals. It is a short-term solution that reinforces gender and socio-economic inequalities. A solution for society as a whole to care of the elderly is only sustainable if it addresses these inequalities in the long run rather than merely the "care crisis" (Schilliger 2014). This means that care work has to be more highly valued. It also means that working conditions and salaries have to be improved so that workers caring for the elderly are able to secure an income that allows them to live in Switzerland. More precisely, care work should enable carers to work shifts and hours comparable to those of local carers in the health sector, to live away from the care recipients and to enable time and capacity for carers to also care for themselves and their own family members.

\section{Acknowledgments}

I am grateful to all interview partners who took their time to share their experiences. Special thanks to Katalin Ráhel Turai for her wonderful collaboration in the field. I am indebted to the members of the Economic Geography Group at the University of Zurich, particularly my project collaborators Karin Schwiter, Katharina Pelzelmayer and Christian Berndt for their generous support during the project. I would like to thank Simon Miligan for his careful editing work. Finally, I would like to thank Vincent Horn and Cornelia Schweppe and the anonymous reviewers for their constructive feedback on earlier versions of this paper. This work was supported by the Swiss National Science Foundation.

\section{Corresponding Author}

Huey Shy Chau, Department of Geography, University of Zurich, Winterthurerstrasse 190, 8057 Zurich, Switzerland. Email: hueyshy.chau@geo. uzh.ch

\section{References}

Abrantes, M. (2014). 'I know it sounds nasty and stereotyped': Searching for the competent domestic worker: Searching for the competent domestic worker. Gender, Work \& Organization 21(5): 1-16. 
Adey, P. (2006). If mobility is everything then it is nothing: Towards a relational politics of (Im)mobilities. Mobilities 1(1): 75-94.

Akalin, A. (2015). Motherhood as the value of labour: The migrant domestic workers' market in Turkey. Australian Feminist Studies 30(83): 65-81.

Bachinger, A. (2009). Der irreguläre Pflegearbeitsmarkt. Zum Transformationsprozess von unbezahlter in bezahlte Arbeit durch die 24-Stunden-Pflege [The Irregular Care Labour Market. Transformation Process from Unpaid to Paid Labour through 24h-Car] Austria: Dissertation at the University of Vienna.

Bakan, A. B. \& Stasiulis, D. K. (1995). Making the match: Domestic placement agencies and the racialization of women's household work. Signs 20(2): 303-335.

Baldassar, L. \& Merla, L. (eds.). (2014). Transnational Families, Migration and the Circulation of Care: Understanding Mobility and Absence in Family Life. New York: Routledge.

Bock, G. \& Duden, B. (1976). Arbeit aus Liebe - Liebe als Arbeit. Zur Entstehung der Hausarbeit im Kapitalismus [Labor of love-love as labor. On the genesis of housework in capitalism]. Frauen und Wissenschaft. Beiträge zur Berliner Sommeruniversität für Frauen [Women and science. Contributions to the Berliner Summer University for Women] 2: 118-199.

Büscher, M. \& Urry, J. (2009). Mobile Methods and the Empirical. European Journal of Social Theory 12(1): 99-116.

Castles, S. (2006). Guest workers in Europe: A Resurrection? International Migration Review 40(4): 741-766.

Charmaz, K. (2014). Constructing Grounded Theory. Thousand Oaks, CA: Sage.

Chau, H. S., Pelzelmayer, K. \& Schwiter, K. (2018). Short-term circular migration and gendered negotiation of the right to the city: The case of migrant live-in care workers in Basel, Switzerland. Cities 76: 4-11.

Constable, N. (1997). Maid to Order in Hong Kong: Stories of Filipina Workers. Ithaca, NY: Cornell University Press.

Cox, R. (2006). The Servant Problem: Domestic Employment in a Global Economy. London: I.B. Tauris.

Cresswell, T. (2006). On the Move: Mobility in the Modern Western World. New York: Routledge. 
International Journal of Ageing and Later Life

Cresswell, T. (2010). Towards a politics of mobility. Environment and Planning D: Society and Space 28(1): 17-31.

Cresswell, T., Dorow, S. \& Roseman, S. (2016). Putting mobility theory to work: Conceptualizing employment-related geographical mobility. Environment and Planning A: Economy and Space 48(9): 1787-1803.

Cresswell, T. \& Merriman, P. (eds.). (2011). Geographies of Mobilities: Practices, Spaces, Subjects. Burlington, VT: Ashgate.

Cuban, S. (2013). Deskilling Migrant Women in the Global Care Industry. London: Palgrave Macmillan UK.

Cuban, S. \& Fowler, C. (2012). Carers cruising Cumbria and meals on the mile: The drive of migrants in fieldwork and fiction. Mobilities 7(2): 295-315.

Denzin, N.K. \& Lincoln, Y.S. (eds.). (2001). The Sage Handbook of Qualitative Research. 4th ed. Thousand Oaks, CA: Sage.

Dorow, S. \& Mandizadza, S. (2018). Gendered circuits of care in the mobility regime of Alberta's oil sands. Gender, Place \& Culture 25(8) 1-16.

Dorow, S., Roseman, S. R. \& Cresswell, T. (2017). Re-working mobilities: Emergent geographies of employment-related mobility. Geography Compass 11(12): 1-12.

Eelens, F. \& Speckmann, J.D. (1990). Recruitment of Labor Migrants for the Middle East: The Sri Lankan Case. The International Migration Review 24: 297-322.

EGB, Eidgenössisches Büro für Gleichstellung von Frau und Mann [Office for equality between women and men] (2010). Anerkennung und Aufwertung der Care-Arbeit. Impulse aus Sicht der Gleichstellung [Recognition and Appreciation of Care Work. Impulses on Equality] Bern: Eidgenössisches Büro für Gleichstellung von Frau und Mann.

Ehrenreich, B. \& Hochschild, A. (2003). Global Woman: Nannies, Maids and Sex Workers in the New Economy. London: Granta Books.

Elrick, T. \& Lewandowska, E. (2008). Matching and making labour demand and supply: Agents in polish migrant networks of domestic elderly care in Germany and Italy. Journal of Ethnic and Migration Studies 34(5): $717-734$.

Faist, T. (2012). Toward a transnational methodology: Methods to address methodological nationalism, essentialism, and positionality. Revue Européenne Des Migrations Internationales 28(1): 51-70. 
Goh, C., Wee, K. \& Yeoh, B. S. A. (2017). Migration governance and the migration industry in Asia: moving domestic workers from Indonesia to Singapore. International Relations of the Asia-Pacific 17(3): 401-433.

Guevarra, A. R. (2010). Marketing Dreams, Manufacturing Heroes: The Transnational Labor Brokering of Filipino Workers. New Brunswick, N.J: Rutgers University Press.

Hanson, S. \& Pratt, G. (1995). Gender, Work, and Space. New York, NY: Psychology Press.

Hesse-Biber, S. (ed.). (2012). Handbook of Feminist Research: Theory and Praxis. 2nd ed. Thousand Oaks: Sage.

Hochschild, A. R. (2000). Global care chains and emotional surplus value. In A. Giddens \& W. Hutton (eds.), On the Edge: Globalization and the New Millenium (pp. 130-146). London: Sage.

Hondagneu-Sotelo, P. (1997). Domestic Employment Agencies in Los Angeles. Los Angeles, CA: University of Southern California, Southern California Studies Center.

Hondagneu-Sotelo, P. (2000). Doméstica: immigrant workers cleaning and caring in the shadows of affluence. Berkeley, CA: University of California Press.

Huang, S., Thang, L. L. \& Toyota, M. (2012). Transnational mobilities for care: Rethinking the dynamics of care in Asia. Global Networks 12(2): 129-134.

Huang, S. \& Yeoh, B. S.A (1996). Ties that bind: State policy and migrant female domestic helpers in Singapore. Geoforum 27(4): 479-493.

Kern, A. \& Müller-Böker, U. (2015). The middle space of migration: A case study on brokerage and recruitment agencies in Nepal. Geoforum 65: 158-169.

Kofman, E. \& Raghuram, P. (2015). Gendered Migrations and Global Social Reproduction. New York, NY: Palgrave Macmillan.

Krawietz, J. (2014). Pflege grenzüberschreitend organisieren. Eine Studie zur transnationalen Vermittlung von Care-Arbeit [Organising transnational care. A study on transnationale placements of care work]. Frankfurt am Main: Mabuse-Verlag.

Liang, L.-F. (2011). The making of an 'ideal' live-in migrant care worker: recruiting, training, matching and disciplining. Ethnic and Racial Studies 34(11): 1815-1834. 
International Journal of Ageing and Later Life

Lindquist, J. (2010). Labour recruitment, circuits of capital and gendered mobility: Reconceptualizing the Indonesian migration industry. Pacific Affairs 83(1): 115-132.

Lindquist, J. (2012). The elementary school teacher, the thug and his grandmother: Informal brokers and transnational migration from Indonesia. Pacific Affairs 85(1): 69-89.

Lindquist, J., Xiang B. \&. Yeoh, B.S.A. 2012. Opening the black box of migration: Brokers, the organization of transnational mobility and the changing political economy in Asia. Pacific Affairs 85(1): 7-19.

Loveband, A. (2004). Positioning the product: Indonesian migrant women workers in Taiwan. Journal of Contemporary Asia 34(3): 336-348.

Lutz, H. (2005). Der Privathaushalt Als Weltmarkt Für Weibliche Arbeitskräfte [The Private Household As A World Market For Female Workers]. Peripherie 25 (97/98): 65-87.

Lutz, H. (2008). Migration and Domestic Work: A European Perspective on a Global Theme. Aldershot, UK: Ashgate.

Lutz, H. (2011). The New Maids: Transnational Women and the Care Economy. London: Zed Books.

Mahler, S. J. \& Pessar, P. R. (2001). Gendered geographies of power: Analyzing gender across transnational spaces. Identities 7(4): 441-459.

Massey, D. (1993). Power-geometry and a progressive sense of place. In J. Bird (ed.), Mapping the Futures: Local Cultures, Global Change. New York: Routledge.

McDowell, L. (2009). Working Bodies: Interactive Service Employment and Workplace Identities. Malden, MA: Wiley-Blackwell.

Österle, A., Hasl, A. \& Bauer, G. (2013). Vermittlungsagenturen in der 24-h-Betreuung [Placement agencies in 24h care]. WISO. Institut für Sozial- und Wirtschaftswissenschaften 36(1): 159-172.

Parrenas, R. S. (2000). Migrant filipina domestic workers and the international division of reproductive labor. Gender \& Society 14(4): 560-581.

Pelzelmayer, K. (2016). Places of difference: Narratives of heart-felt warmth, ethnicisation, and female care-migrants in Swiss live-in care. Gender, Place \& Culture 23(12):1701-1712.

Raghuram, P. (2012). Global care, local configurations - Challenges to conceptualizations of care. Global Networks 12(2): 155-174.

Raghuram, P. (2016). Locating care ethics beyond the Global North. ACME: An International Journal for Critical Geographies 15(3): 511-533. 
Razavi, S. (2007). The Political and Social Economy of Care in a Development Context: Conceptual Issues, Research Questions and Policy Options. Gender and Development Paper No. 3. p. 50. Geneva: UNRISD.

Roseman, S. R., Barber, P. G. \& Neis, B. (2015). Towards a feminist political economy framework for analyzing employment-related geographical mobility. Studies in Political Economy 95(1): 175-203.

Rossow, V. \& Leiber, S. (2017). Zwischen Vermarktlichung und Europäisierung: Die wachsende Bedeutung transnational agierender Vermittlungsagenturen in der häuslichen Pflege in Deutschland [Between Marketization and Europeanisation: The growing significance of transnational employment agencies for home care in Germany]. Sozialer Fortschritt 66(3-4): 285-302.

Schilliger, S. (2009). Hauspflege: Aktuelle Tendenzen in der Entstehung eines globalisierten, deregulierten Arbeitsmarktes [Home care: Current developments in the emergence of a globalised, deregulised labour market]. Olympe. Feministische Arbeitshefte zur Politik 30: 121-126.

Schilliger, S. (2014). Pflegen ohne Grenzen? Polnische Pendelmigrantinnen in der 24h-Betreuung. Eine Ethnographie des Privathaushalts als globalisiertem Arbeitsplatz [Caring without borders? Polish circular migrants in $24 \mathrm{~h}$ care: An ethnography of the private household as a globalised workplace]. Switzerland: Dissertation at the University of Basel.

Schilliger, S. (2015). 'Wir sind doch keine Sklavinnen'. (Selbst-)Organisierung von polnischen Care-Arbeiterinnen in der Schweiz ['We are no slaves'. (Self-)organizing of Polish care workers in Switzerland]. In Denknetz (ed.), Zerstörung und Transformation des Gemeinwesens (vol. 8, 8th ed., pp. 164-177). Edition 8: Zürich.

Schwiter, K., Berndt, C. \& Schilling, L. (2014). Ein sorgender Markt. Wie transnationale Vermittlungsagenturen von Betagtenbetreuerinnen (Im) Mobilität, Ethnizität und Geschlecht in Wert setzen [A caring market. How transnational care agencies put (im)mobility, ethnicity and gender in value]. Geographischen Zeitschrift 102(4): 2012-2231.

Schwiter, K., Berndt, C. \& Truong, J. (2018). Neoliberal austerity and the marketisation of elderly care. Social \& Cultural Geography 19(2): 379-399.

Sheller, M. (2016). Uneven mobility futures: A Foucauldian approach. Mobilities 11(1): 15-31.

Sheller, M. \& Urry, J. (2006). The new mobilities paradigm. Environment and Planning A 38(2): 207-226. 
International Journal of Ageing and Later Life

Strauss, A. \& Corbin, J. (1990). Basics of Qualitative Research. Techniques and Procedures for Developing Theory. Newbury Park, CA: Sage.

Triandafyllidou, A. \& Marchetti, S. (2013). Migrant domestic and care workers in Europe: New patterns of circulation? Journal of Immigrant $\mathcal{E}$ Refugee Studies 11(4): 339-346.

Truong, J., Schwiter, K. \& Berndt, C. (2012). Arbeitsmarkt Privathaushalt. Charakteristika der Unternehmen, deren Beschäftigungsstruktur und Arbeitsbedingungen. Eine Studie im Auftrag der Fachstelle für Gleichstellung der Stadt Zürich [Private household as labour market. A study commissioned by the Office for equality]. Zürich: Department of Geography, University of Zurich.

Urry, J. (2003). Global Complexity. Cambridge, UK: Polity Press.

Urry, J. (2007). Mobilities. Cambridge, UK: Polity Press.

Wickramasekara, P. (2011). Circular migration: A triple win or a dead end? International Labour Office. Bureau for Workers' Activities 15: 1-108.

Williams, F. (2011). Markets and migrants in the care economy. Soundings 47: 22-33.

XE Currency Converter. (2017). Available on http://www.xe.com/de/currencytables/?from=CHF\&date=2014-05-15 (Accessed: August 17, 2017)

Yeates, N. (2004). Global care chains. International Feminist Journal of Politics 6(3): 369-391.

Yeates, N. (2012). Global care chains: A state-of-the-art review and future directions in care transnationalization research. Global Networks 12(2): 135-154. 